\title{
Reference Range of Complete Blood Count in Healthy Term Newborns 1 Week after Birth
}

\author{
Harapan Parlindungan Ringoringo* (i) \\ Department of Child Health, Faculty of Medicine, Lambung Mangkurat University, RSD Idaman, Banjarbaru, Indonesia
}

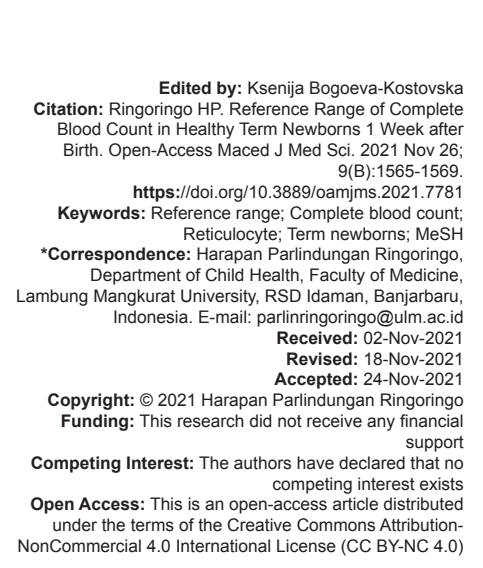

Introduction

The reference range of the complete blood count $(\mathrm{CBC})$ and reticulocyte in the newborn is limited, especially in Indonesia. Meanwhile, determining the reference range of the $\mathrm{CBC}$ and reticulocyte value is very important to help doctors when a newborn baby looks pale, has bleeding, or has a neonatal infection in subsequent care. That is why determining the reference range of the $\mathrm{CBC}$ and reticulocyte in the newborn is crucial.

All ages' anemia prevalence was $22.8 \%$ globally in 2019. The prevalence was highest among children under 5 years, $39.7 \%$, with the most contributing cause, was dietary iron deficiency (ID) [1]. Anemia defined as a low hemoglobin $(\mathrm{Hb})$ concentration according to age. Anemia is still a global public health problem, so early detection is crucial to prevent it. Aziz et al.'s study found that the prevalence of ID anemia (IDA) at birth was $22.8 \%$ from 368 term newborns [2]. Meanwhile, another study of 211 newborns found that the incidence of iron depletion, ID, and IDA was $9.5 \%, 14.2 \%$, and $11.85 \%$, respectively [3].

Low iron stores at birth, eminent postnatal growth velocity, and iron loss cause ID [4], [5], [6].
Iron plays a key role in developing the central nervous system and is essential to neural myelination and neurotransmitter function [7], [8]. Therefore, starting early enteral iron supplementation in term newborns is proposed to avert ID [3]. If oral iron supplementation is late to an infant, neurological disorders will manifest in the long term [9]. Although ID can be corrected by iron supplementation, the cognitive and behavioral deteriorations observed in children with ID may not be completely restorable [10], [11]. Thus, some term infants still develop ID even with iron supplementation so that early ID detection would be ideal.

The purposefulness of the lower limit of $\mathrm{Hb}$ concentration to declare someone anemic or not depends on the person's age, type of race, gender, and demographics area in which the person lives. On the other hand, other erythrocyte indices reference range is needed to establish the diagnosis of anemia. Moreover, determining the CBC and reticulocyte reference range helps diagnose a disease related to erythrocyte indices, white blood count, platelets, and reticulocytes. Therefore, the study aims to establish reference range of $C B C$ and reticulocyte in healthy term newborns 1 week after birth. 


\section{Material and Methods}

\section{Study population}

This prospective analysis was carried out at a secondary hospital evaluating laboratory data obtained as a routine admission procedure. The research sample was a newborn baby delivered from April 2018 to December 2018 (9 months period) at Idaman Banjarbaru Hospital. Inclusion criteria are term newborn (gestational age 37-42 weeks) with good tone, breathing, or crying immediately, do not have resuscitation, and the birth weight is $\geq 2500 \mathrm{~g}$ [12]. Exclusion criteria were hematological diseases, congenital anomalies, or the lack of a CBC within 1 week after birth. In addition, gestational age, birth weight and length, and head and chest circumference were obtained from the newborn's medical record. All of the newborn's parents had signed the informed consent. This study had obtained ethical clearance from the Research Ethics Commission of Medical Faculty of the University of Lambung Mangkurat No. 535/KEPK-FK ULM/EC/II/2021.

\section{Blood sampling}

Every newborn who meets the inclusion and exclusion criteria will be taken a blood sample of $1 \mathrm{ml}$ from the median cubital vein. The blood sample was put in a tube with EDTA anticoagulant, homogenized by turning it over, and stored in a storage box. Then, the blood sample was sent to the Banjarbaru Idaman Hospital Laboratory. CBC examinations were carried out by inserting a sample of the baby's blood into the Sysmex XN-450 Hematology Analyzer.

\section{Statistical analysis}

All newborn anthropometry measurements and laboratory findings of $\mathrm{CBC}$ and reticulocyte are analyzed by SPSS ver.25 for P2.5, P3, P5, P95, P97, P97.5, and mean and standard deviation (SD). All data are presented

\section{Discussion}

Ferritin, soluble transferrin receptor (sTfR), and transferrin saturation are the best parameters to assess a person's iron status, including newborns. One study, using indicators of CBC, ferritin, STfR, and transferrin saturation, found that the incidence of iron depletion, ID, and IDA was highest in infants aged 0 months, $9.5 \%, 14.2 \%$, and $11.8 \%$, respectively [3]. The problem is that the examination requires substantial blood, is influenced by the diurnal phase, inflammation, infection, is expensive, and is limited to specific health facilities. This research is intended to find alternative tests that can determine the iron status of newborns 1 week after birth and to evaluate the severity of the ID so can make early prompt treatment of ID. The CBC examination can be performed in conjunction with the peripheral blood smear examination. The blood drawn is small, easy to do, cheap, not affected by inflammatory or infectious factors, and widely available in health facilities.

In 2008, a study in newborns showed a reference range of $\mathrm{CBC}$ values with P2.5-P97.5 [13]. However, in the past 13 years, there has been no updated data of the CBCs reference range for healthy term newborns. The in-charge doctor ensures the healthiness of newborns by physical examination with good tone, breathing, or crying immediately, does not have resuscitation weighing $>2500 \mathrm{~g}$. The lower limits of body length and head circumference of all infants in this study were above the WHO growth curve's $3^{\text {rd }}$ percentile (P3); this further confirms that all infants were healthy and physically normal in size [14]. This study showed the reference range of $\mathrm{CBC}$ and reticulocyte at $\mathrm{P} 2.5$ P97.5, P3-P97, P5-P95, and mean \pm 2SD. Thus, for example, this study indicates that the lower limit of $\mathrm{Hb}$ for healthy term newborns can be taken at P2.5, P3, P5, or mean-2SD, that is, $11.70 \mathrm{~g} / \mathrm{dL}, 11.90 \mathrm{~g} / \mathrm{dL}, 12.2 \mathrm{~g} / \mathrm{dL}$, or $11.35 \mathrm{~g} / \mathrm{dL}$, respectively. This study also showed that the P2.5, P3, P5, and mean-2SD values of $\mathrm{Hb}$ for male newborns were $12.20 \mathrm{~g} / \mathrm{dL}, 12.28 \mathrm{~g} / \mathrm{dL}, 12.63 \mathrm{~g} / \mathrm{dL}$, or

Table 1: The reference range of $\mathrm{CBC}$ and reticulocyte in healthy term newborns 1 week after birth

\begin{tabular}{|c|c|c|c|c|c|}
\hline CBC & $N$ & $\mathrm{P}_{2.5} \mathrm{P}_{97.5}$ & $P_{3}-P_{97}$ & $P_{5}-P_{95}$ & Mean $\pm 2 \mathrm{SD}$ \\
\hline WBC $\left(10^{3} / \mathrm{uL}\right)$ & 277 & $8.04-30.37$ & $8.37-30.11$ & $9.23-26.14$ & $6.83-28.31$ \\
\hline $\operatorname{RBC}\left(10^{6} / \mathrm{uL}\right)$ & 277 & $3.25-5.55$ & $3.31-5.49$ & $3.41-5.37$ & $3.25-5.53$ \\
\hline $\mathrm{HGB}(\mathrm{g} / \mathrm{dL})$ & 277 & $11.70-19.60$ & $11.90-19.57$ & $12.20-19.20$ & $11.35-19.63$ \\
\hline HCT (\%) & 277 & $33.79-56.11$ & $34.20-55.83$ & $35.20-54.21$ & $33.22-55.74$ \\
\hline MCV (fL) & 277 & $92.59-111.63$ & $92.83-110.97$ & $93.86-109.61$ & $92.37-110.49$ \\
\hline $\mathrm{MCH}(\mathrm{pg})$ & 277 & $31.59-38.81$ & $32.04-38.70$ & $32.59-38.11$ & $31.99-38.55$ \\
\hline $\mathrm{MCHC}(\mathrm{g} / \mathrm{dL})$ & 277 & $33.00-36.50$ & $33.13-36.40$ & $33.30-36.20$ & $32.7-36.78$ \\
\hline PLT $\left(10^{3} / \mathrm{ul}\right)$ & 277 & $118.60-413.15$ & $128.68-408.60$ & $154.70-390.10$ & $137.18-411.74$ \\
\hline RDW SD (fL) & 277 & $50.60-73.51$ & $50.87-72.73$ & $52.47-70.57$ & $49.29-70.61$ \\
\hline RDW CV (\%) & 277 & $14.40-20.01$ & $14.50-19.70$ & $14.60-19.00$ & $13.72-19.04$ \\
\hline PDW (fL) & 277 & $8.90-15.54$ & $8.90-15.00$ & $9.09-14.40$ & $7.68-14.6$ \\
\hline MPV (fL) & 277 & $9.00-12.11$ & $9.10-11.90$ & $9.10-11.70$ & $8.69-11.81$ \\
\hline PLCR (\%) & 277 & $16.10-39.22$ & $16.80-39.00$ & $17.10-36.00$ & $13.96-37.04$ \\
\hline PCT (\%) & 277 & $0.13-0.40$ & $0.14-0.40$ & $0.17-0.38$ & $0.16-0.4$ \\
\hline Neutro $\left(10^{3} / \mathrm{uL}\right)$ & 277 & $3.47-21.37$ & $3.67-20.91$ & $3.94-19.83$ & $1.72-20.32$ \\
\hline Lymph (103/uL) & 277 & $2.51-6.78$ & $2.57-6.74$ & $2.64-6.18$ & $2.03-6.43$ \\
\hline Mono (103/uL) & 277 & $0.86-3.48$ & $0.88-3.41$ & $0.97-3.15$ & $0.5-3.1$ \\
\hline Eosinophils $\left(10^{3} / \mathrm{uL}\right)$ & 277 & $0.7-1.22$ & $0.08-1.18$ & $0.09-1.06$ & $0-100$ \\
\hline Eosinophils absolute $\left(10^{3} / \mathrm{uL}\right)$ & 277 & $1082.65-26356.28$ & $1156.96-25602.86$ & $1781.76-21922.39$ & $0-100$ \\
\hline Basophils $\left(10^{3} / \mathrm{uL}\right)$ & 277 & $0.02-0.18$ & $0.02-0.17$ & $0.03-0.16$ & $0-0.16$ \\
\hline Basophils absolute $\left(10^{3} / \mathrm{uL}\right)$ & 277 & $210.30-4544.55$ & $221.98-4463.82$ & $363.28-3821.85$ & $0-100$ \\
\hline Reticulocyte $\left(10^{6} / \mathrm{uL}\right)$ & 277 & $2.94-7.56$ & $2.99-7.44$ & $3.14-6.72$ & $2.39-6.95$ \\
\hline
\end{tabular}


in narrative and table. Reference range P2.5-P97.5 means that $95 \%$ of normal individuals have normal laboratory results, while the other $5 \%$ may not be sick outside the normal limits. Reference range P3-P97 means that 94\% of normal individuals have normal laboratory results, while the other $6 \%$ may not be sick outside the normal limits, in the same way for P5-P95 and mean \pm 2 SD.

\section{Results}

Two hundred and seventy-seven newborns met the inclusion and exclusion criteria, consisting of $145(52.35 \%)$ male and 132 (47.65\%) female infants.
The birth weight range, the birth length range, the head circumference range, and the chest circumference range are $2,500-4,450 \mathrm{~g}, 44.0-55.0 \mathrm{~cm}, 27.0-37.5 \mathrm{~cm}$, and $26.0-37.5 \mathrm{~cm}$, respectively. In addition, reference range of $\mathrm{CBC}$ and reticulocyte in healthy term newborns 1 week after birth is shown in Tables 1-3. Table 1 shows the reference range of $\mathrm{CBC}$ and reticulocyte from the $2.5^{\text {th }}$ to $97.5^{\text {th }}$ percentiles, $3^{\text {th }}$ to $97^{\text {th }}$ percentiles, $5^{\text {th }}$ to $95^{\text {th }}$ percentiles, and mean $\pm 2 S D$ for all newborns. Table 2 shows the reference range of $\mathrm{CBC}$ and reticulocyte from the $2.5^{\text {th }}$ to $97.5^{\text {th }}$ percentiles, $3^{\text {th }}$ to $97^{\text {th }}$ percentiles, $5^{\text {th }}$ to $95^{\text {th }}$ percentiles, and mean \pm 2SD for male newborns. Finally, Table 3 shows the reference range of $\mathrm{CBC}$ and reticulocyte from the $2.5^{\text {th }}$ to $97.5^{\text {th }}$ percentiles, $3^{\text {th }}$ to $97^{\text {th }}$ percentiles, $5^{\text {th }}$ to $95^{\text {th }}$ percentiles, and mean \pm 2 SD for female newborns.

Table 2: Reference range of $\mathrm{CBC}$ and reticulocyte in healthy term male newborns 1 week after birth

\begin{tabular}{|c|c|c|c|c|c|}
\hline$\overline{\mathrm{CBC}}$ & $n$ & $\mathrm{P}_{2.5}-\mathrm{P}_{97.5}$ & $\mathrm{P}_{3}-\mathrm{P}_{97}$ & $\mathrm{P}_{5}-\mathrm{P}_{95}$ & Mean \pm 2SD \\
\hline WBC $\left(10^{3} / \mathrm{uL}\right)$ & 145 & $8.52-30.69$ & $8.71-29.13$ & $9.32-24.62$ & $6.36-25.76$ \\
\hline $\operatorname{RBC}\left(10^{6} / \mathrm{uL}\right)$ & 145 & $3.41-5.63$ & $3.42-5.57$ & $3.59-5.42$ & $3.35-5.59$ \\
\hline HGB $(g / d L)$ & 145 & $12.20-20.14$ & $12.28-19.91$ & $12.63-19.38$ & $11.47-20.15$ \\
\hline HCT (\%) & 145 & $34.47-56.90$ & $34.73-56.63$ & $35.95-55.04$ & $33.62-56.5$ \\
\hline MCV (fL) & 145 & $92.87-110.12$ & $93.01-109.66$ & $94.02-107.27$ & $92.58-109.3$ \\
\hline $\mathrm{MCH}(\mathrm{pg})$ & 145 & $32.43-38.38$ & $32.54-38.05$ & $32.60-37.60$ & $32.3-38.22$ \\
\hline $\mathrm{MCHC}(\mathrm{g} / \mathrm{dL})$ & 145 & $32.96-36.54$ & $33.24-36.50$ & $33.33-36.37$ & $32.53-37.21$ \\
\hline $\operatorname{PLT}\left(10^{3} / \mathrm{ul}\right)$ & 145 & $101.55-424.05$ & $106.66-419.20$ & $132.80-396.20$ & $124.93-408.77$ \\
\hline RDW SD (fL) & 145 & $50.57-72.41$ & $50.75-72.22$ & $52.73-70.50$ & $49.44-69.92$ \\
\hline RDW CV (\%) & 145 & $14.40-19.44$ & $14.44-19.19$ & $14.50-18.97$ & $13.79-18.95$ \\
\hline PDW (fL) & 145 & $8.70-16.34$ & $8.78-15.81$ & $8.96-14.44$ & $7.78-14.46$ \\
\hline MPV (fL) & 145 & $9.07-12.24$ & $9.10-12.09$ & $9.10-11.81$ & $8.69-11.81$ \\
\hline PLCR (\%) & 145 & $16.56-39.88$ & $16.84-39.37$ & $17.10-35.87$ & $13.86-37.02$ \\
\hline РCT (\%) & 145 & $0.12-0.40$ & $0.12-0.40$ & $0.16-0.38$ & $0.15-0.39$ \\
\hline Neutro $\left(10^{3} / \mathrm{uL}\right)$ & 145 & $3.25-22.52$ & $3.57-21.42$ & $3.83-19.05$ & $0.99-20.23$ \\
\hline Lymph $\left(10^{3} / \mathrm{uL}\right)$ & 145 & $2.44-6.79$ & $2.51-6.73$ & $2.60-6.10$ & $1.94-6.22$ \\
\hline Mono $\left(10^{3} / \mathrm{uL}\right)$ & 145 & $0.86-3.28$ & $0.87-3.17$ & $0.98-2.97$ & $0.57-2.93$ \\
\hline Eosinophils $\left(10^{3} / \mathrm{uL}\right)$ & 145 & $0.04-1.17$ & $0.06-1.13$ & $0.13-1.07$ & $0-100$ \\
\hline Eosinophils absolute $\left(10^{3} / \mathrm{uL}\right)$ & 145 & $906.42-26162.07$ & $1268.27-25587.84$ & $1903.60-21988.33$ & $0-100$ \\
\hline Basophils $\left(10^{3} / \mathrm{uL}\right)$ & 145 & $0.02-0.21$ & $0.02-0.21$ & $0.03-0.17$ & $0-100$ \\
\hline $\begin{array}{l}\text { Basophils } \\
\text { absolute }\left(10^{3} / \mathrm{uL}\right)\end{array}$ & 145 & $192.86-5055.90$ & $209.16-4176.37$ & $327.51-3746.19$ & $0-100$ \\
\hline Reticulocyte $\left(10^{6} / \mathrm{uL}\right)$ & 145 & $2.70-7.06$ & $2.83-7.02$ & $2.99-6.58$ & $2.3-6.5$ \\
\hline
\end{tabular}

$11.47 \mathrm{~g} / \mathrm{dL}$, respectively. For female newborns, the P2.5, $\mathrm{P} 3, \mathrm{P} 5$, and mean-2SD values of $\mathrm{Hb}$ were $11.37 \mathrm{~g} / \mathrm{dL}$, $11.50 \mathrm{~g} / \mathrm{dL}, 11.80 \mathrm{~g} / \mathrm{dL}$, or $11.37 \mathrm{~g} / \mathrm{dL}$, respectively.

By knowing the lower limit of the reference range of $\mathrm{CBC}$ and reticulocyte, we can determine ID and IDA with a combination of erythrocyte indices and peripheral blood smear. Determination of the CBC and reticulocyte reference range also helps establish a disease related to changes in the white blood counts value, platelets, basophils, eosinophils, neutrophil band, neutrophil segments, lymphocyte, monocytes, and reticulocyte, especially in newborns.

Keohane et al. obtained reference range of CBC data from Riley Hospital for Children, Indiana University

Table 3: Reference range of $\mathrm{CBC}$ and reticulocyte in healthy term female newborns 1 week after birth

\begin{tabular}{|c|c|c|c|c|c|}
\hline CBC & $n$ & $\mathrm{P}_{2.5}-\mathrm{P}_{97.5}$ & $\mathrm{P}_{3}-\mathrm{P}_{97}$ & $\mathrm{P}_{5}-\mathrm{P}_{95}$ & Mean \pm 2SD \\
\hline WBC $\left(10^{3} / \mathrm{uL}\right)$ & 132 & $7.83-31.00$ & $8.01-30.21$ & $8.100-28.71$ & $7.47-29.03$ \\
\hline $\operatorname{RBC}\left(10^{6} / \mathrm{uL}\right)$ & 132 & $3.10-5.49$ & $3.15-5.48$ & $3.23-5.27$ & $3.15-5.47$ \\
\hline $\mathrm{HGB}(\mathrm{g} / \mathrm{dL})$ & 132 & $11.37-19.20$ & $11.50-19.20$ & $11.80-19.20$ & $11.37-18.93$ \\
\hline НCT (\%) & 132 & $32.77-55.84$ & $32.90-55.51$ & $34.52-54.07$ & $32.89-54.77$ \\
\hline $\mathrm{MCV}(\mathrm{fL})$ & 132 & $91.03-112.90$ & $91.69-112.70$ & $93.16-110.81$ & $92.29-111.65$ \\
\hline $\mathrm{MCH}(\mathrm{pg})$ & 132 & $30.80-39.20$ & $30.100-39.00$ & $32.16-38.51$ & $31.68-38.88$ \\
\hline $\mathrm{MCHC}(\mathrm{g} / \mathrm{dL})$ & 132 & $33.00-36.20$ & $33.00-36.20$ & $33.20-36.10$ & $32.97-36.21$ \\
\hline $\operatorname{PLT}\left(10^{3} / \mathrm{ul}\right)$ & 132 & $133.58-402.00$ & $140.89-402.00$ & $188.65-390.35$ & $152.33-413.33$ \\
\hline RDW SD (fL) & 132 & $49.92-75.47$ & $50.79-75.20$ & $52.17-71.76$ & $49.15-71.35$ \\
\hline RDW CV (\%) & 132 & $14.47-20.40$ & $14.60-20.20$ & $14.67-19.51$ & $13.65-19.13$ \\
\hline PDW (fL) & 132 & $8.90-15.34$ & $8.90-15.01$ & $9.07-14.40$ & $7.59-14.75$ \\
\hline MPV (fL) & 132 & $8.93-12.00$ & $8.100-11.80$ & $9.10-11.70$ & $8.7-11.82$ \\
\hline PLCR (\%) & 132 & $15.93-39.14$ & $15.100-39.00$ & $17.20-36.53$ & $14.01-37.13$ \\
\hline РCT (\%) & 132 & $0.16-0.41$ & $0.17-0.40$ & $0.20-0.38$ & $0-100$ \\
\hline Neutro $10^{3} / \mathrm{uL}$ ) & 132 & $3.27-21.27$ & $3.64-21.12$ & $4.45-19.96$ & $2.58-20.34$ \\
\hline Lymph (103/uL) & 132 & $2.55-6.87$ & $2.63-6.78$ & $2.67-6.25$ & $2.16-6.64$ \\
\hline Mono $\left(10^{3} / \mathrm{uL}\right)$ & 132 & $0.87-3.91$ & $0.88-3.75$ & $0.92-3.37$ & $0.45-3.25$ \\
\hline Eosinophils $\left(10^{3} / \mathrm{uL}\right)$ & 132 & $0.07-1.34$ & $0.08-1.29$ & $0.09-1.05$ & $0-100$ \\
\hline Eosinophils absolute $\left(10^{3} / \mathrm{uL}\right)$ & 132 & 1037.23-28381.99 & $1152.27-26348.09$ & $1547.16-21764.18$ & $0-100$ \\
\hline Basophils (10/uL) & 132 & $0.02-0.17$ & $0.02-0.17$ & $0.03-0.16$ & $0-0.16$ \\
\hline Basophils absolute $\left(10^{3} / \mathrm{uL}\right)$ & 132 & $262.20-4726.43$ & $320.72-4532.91$ & $398.65-4070.68$ & $0-100$ \\
\hline Reticulocyte $\left(10^{6} / \mathrm{uL}\right)$ & 132 & $3.21-8.50$ & $3.24-7.92$ & $3.34-7.38$ & $2.68-7.28$ \\
\hline
\end{tabular}


Health, Indianapolis. Hence, the lower limit value of the $C B C$ is higher than the results of this study [15]. While The American Association of Pediatrics lists the reference range of $\mathrm{CBC}$ with $\mathrm{P} 2.5-\mathrm{P} 97.5$, the value is also higher than the results of this study [16]. This difference may be due to differences in genetics, race, ethnicity, parity, and nutritional/iron status of the mother.

Determining the lower limit of P2.5, P3, P5, or mean-2SD on examining specific parameters is commonly used statistically. For example, the WHO and CDC growth charts set the lower limit of weight-for-age, length/height-for-age, head circumference-for-age, and arm circumference-for-age at P3 [17]. Beutler et al. set the lower limit of $\mathrm{Hb}$ at P2.5 to state someone is anemic or not [18], while Goyette and Janus used the lower limit of P5 [19], [20]. Beutler stated that determining the lower limit of $\mathrm{Hb}$ with $\mathrm{P} 2.5$, or $\mathrm{P} 5$, of course, by considering race, ethnicity, age, gender, altitude above sea level [21]. Ariati et al. stated that the undernutrition and poor malnutrition were categorized into undernutrition status with a z-score <-2 SD [22]. Lotti et al. used the lower limit of the parameter is Mean $\pm 2 S D$, with the lower limit being <-2SD [23].

\section{Conclusion}

The advantage of this study is that it parades all $\mathrm{CBC}$ and reticulocyte reference range at P2.5P97.5, P3-P97, P5-P95, and mean $\pm 2 S D$. Thus, the reference range of $\mathrm{CBC}$ and reticulocyte for healthy term newborns, male newborns, and female newborns in this study can be used as a benchmark. The limitation of this study is that the altitude, genetics, and the racial makeup of our population differ from populations in other areas of the world, and whether such differences are pertinent to $\mathrm{CBC}$ and reticulocyte parameters of neonates are not known. In the future, the methods of this study can be adapted to examine other markers of anemia (ferritin, sTfR, transferrin saturation, and C-reactive protein) to assist a more reliable diagnosis.

\section{References}

1. Gardner W, Kassebaum N. Global, regional, and national prevalence of anemia and its causes in 204 countries and territories, 1990-2019. Curr Dev Nutr. 2020;4:830-0.

2. Aziz A, Sultana H, Qadir S, Ashraf S, Masood MS. Frequency of fetal iron deficiency anemia at the time of birth in obese mothers. Prof Med J. 2021;28(7):973-7

3. Ringoringo HP, Wahidiyat I, Sutrisna B, Setiabudy R, Suradi R, Setiabudy R, et al. Saat terbaik pemberian suplementasi zat besi pada bayi 0 bulan sampai 6 bulan. Sari Pediatr. 2016;10:163.

4. Lorenz L, Peter A, Poets CF, Franz AR. A review of cord blood concentrations of iron status parameters to define reference range for preterm infants. Neonatology. 2013;104(3):194-202. https://doi.org/10.1159/000353161

PMid:23989077

5. Niklasson A, Engström E, Hård AL, Wikland KA, Hellström A Growth in very preterm children: A longitudinal study. Pediatr Res. 2003;54:899-905. https://doi.org/10.1203/01. PDR.0000091287.38691.EF

PMid:12930904

6. Widness JA. Reduction in red blood cell transfusions among preterm infants: Results of a randomized trial with an in-line blood gas and chemistry monitor. Pediatrics. 2005;115:1299-306. https://doi.org/10.1542/peds.2004-1680

PMid:15867038

7. Andersson $\mathrm{O}$, Lindquist $\mathrm{B}$, Lindgren $\mathrm{M}$, Stjernqvist $\mathrm{K}$ Domellöf M, Hellström-Westas L. Effect of delayed cord clamping on neurodevelopment at 4 years of age. JAMA Pediatr. 2015;169(7):631-8. https://doi.org/10.1001/ jamapediatrics.2015.0358

PMid:26010418

8. Beard JL. Why iron deficiency is important in infant development. J Nutr. 2008;138(12):2534-6. https://doi.org/10.1093/ jn/138.12.2534

PMid:19022985

9. Steinmacher J, Pohlandt F, Bode H, Sander S, Kron M, Franz AR. Randomized trial of early versus late enteral iron supplementation in infants with a birth weight of less than 1301 grams: Neurocognitive development at 5.3 years' corrected age. Pediatrics. 2007;120:53846. https://doi.org/10.1542/peds.2007-0495 PMid:17766527

10. Szajewska H, Ruszczynski M, Chmielewska A. Effects of iron supplementation in nonanemic pregnant women, infants, and young children on the mental performance and psychomotor development of children: A systematic review of randomized controlled trials. Am J Clin Nutr. 2010;91:1684-90. https://doi. org/10.3945/ajcn.2010.29191 PMid:20410098

11. Lozoff B, Georgieff MK. Iron deficiency and brain development Semin Pediatr Neurol. 2006;13:158-65. https://doi.org/10.1016/j. spen.2006.08.004

PMid:17101454

12. Wyckoff MH, Aziz K, Escobedo MB, Kapadia VS, Kattwinkel J, Perlman JM, et al. Part 13: Neonatal resuscitation: 2015 American heart association guidelines update for cardiopulmonary resuscitation and emergency cardiovascular care. Circulation. 2015;132(17):S543-60. https://doi. org/10.1161/CIR.0000000000000267 PMid:26473001

13. Ringoringo HP. Pendekatan Diagnostik Status Besi Bayi Berusia 0 Bulan Sampai 6 Bulan di Banjarbaru: Saat Terbaik Pemberian Suplementasi Zat Besi. Indonesia: University of Indonesia; 2008.

14. World Health Organization. Head Circumference for Age. Available from: https://www.who.int/tools/child-growthstandards/standards/head-circumference-for-age [Last accessed on 2021 Oct 19].

15. Keohane EM, Otto CN. Rodak's Hematology; Clinical Priciples and Applications. $6^{\text {th }}$ ed. St Louis Missouri: Elsevier; 2020.

16. Soghier L, Fratanotni K. Reference Range Values for Pediatric Care. $2^{\text {nd }}$ ed. New Delhi: AAP; 2019.

17. World Health Organization Child Growth Standards. Available from: https://www.who.int/tools/child-growth-standards/ standards/weight-for-age [Last accessed on 2021 Oct 19].

18. Beutler E, Lichtman MA, Coller BS, Kipps TJ. Williams Hematology. New York: McGraw-Hill; 2001. 
19. Goyette MD, Richert E. Hematology. A Comprehensive Guide to the Diagnosis and Treatment of Blood Disorders. Los Angeles, CA: Practice Management Information Corporation; 1997.

20. Janus J, Moerschel SK. Evaluation of anemia in children. Am Fam Physician. 2010;81(12):1462-71.

PMid:20540485

21. Beutler E, Waalen J. The definition of anemia: What is the lower limit of normal of the blood hemoglobin concentration? Blood. 2006;107(5):1747-50. https://doi.org/10.1182/blood-2005-07-3046 PMid:16189263
22. Ariati NN, Wiardani NK, Kusumajaya AA, Supariasa ID. Buku Saku Antropometri Gizi Anak PAUD. India: Inteligensia Media (Kelompok Penerbit Intrans Publishing); 2020.

23. Lotti F, Frizza F, Balercia G, Behre HM, Calogero AE, Cremers JF, et al. The European academy of andrology (EAA) ultrasound study on healthy, fertile men: Scrotal ultrasound reference ranges and associations with clinical, seminal, and biochemical characteristics. Andrology. 2021;9(2):559-76. https://doi.org/10.1111/andr.12951

PMid:33244893 